\title{
Total body potassium depletion and severe myopathy due to chronic liquorice ingestion
}

\author{
M. B. M. SUNDARAM \\ M.B. B.S., M.R.C.P. (U.K.)
}

R. SWAMinathaN*

M.B. B.S., Ph.D., M.R.C.Path.

Departments of Neurology and * Chemical Pathology, The General Infirmary at Leeds

\begin{abstract}
Summary
A 33-year-old patient with hypokalaemia associated with severe myopathy following liquorice ingestion is described. Potassium depletion was confirmed by total body potassium measurements and myopathy was established by electromyography and enzyme studies. The potential hazard of chronic liquorice consumption even as a sweet is illustrated by this case.
\end{abstract}

\section{Introduction}

Although liquorice consumption can be one of the causes of hypokalaemia (Conn, Cohen and Rovner, 1968; Cumming, 1977; Gross, Dexter and Roth, 1966; Salassa, Mattox and Rosevear, 1962) there are no reports of total body potassium measurements in patients with hypokalaemia caused by this. This report concerns a patient with severe myopathy and potassium depletion due to chronic liquorice ingestion, in whom total body potassium was measured.

\section{Case report}

A 33-year-old female Civil Servant, was admitted to the General Infirmary at Leeds with a 4-week history of increasingly severe pain and weakness in proximal muscles. Two weeks before admission she had noted slight ankle oedema and had been given bendrofluazide $5 \mathrm{mg}$ once/day by her general practitioner. The weakness increased and by the time of admission she was unable to stand. There was no past or family history of similar symptoms. On admission her BP was $180 / 100 \mathrm{mmHg}$. She had minimal bilateral pitting ankle oedema. The limbs were hypotonic; the patient could not raise her head, arms or legs from the bed; the deep reflexes were absent. However, her respiration was normal.

Investigations showed severe hypokalaemic alkalosis and elevated 'muscle' enzymes (creatine phos phokinase, aldolase and aspartate amino transfere ase) (Table 1). The electrocardiogram was normat and electromyography confirmed that she had myopathy.

On being questioned, the patient admitted that she ate about $500 \mathrm{~g}$ (i.e. 4 boxes) of liquorice a week. This and the diuretic were stopped and she was treated with potassium chloride $64 \mathrm{mmol} / \mathrm{day}$. Muscle power dramatically improved within $48 \mathrm{hr}$ and the patient was able to get up from bed and stand unaided. Her total body potassium (TBK), measured in a total body counter on the 4th day after admission was $1940 \mathrm{mmol} / 1$ (normal 2355-3071 mmol). As shown in

TABle 1. Changes in plasma potassium, bicarbonate, enzymes and total body potassium in a patient with liquorice toxicity

\begin{tabular}{ccccccc}
\hline & $\begin{array}{c}\text { Plasma } \\
\text { potassium } \\
(3 \cdot 5-5 \cdot 0) \\
(\mathrm{mmol} / \mathrm{l})\end{array}$ & $\begin{array}{c}\text { Bicarbonate } \\
(\mathrm{mmol} / \mathrm{l})\end{array}$ & $\begin{array}{c}\text { AST } \\
(\mathrm{GOT}) \\
(8-22)\end{array}$ & $\begin{array}{c}\text { Aldolase } \\
(1-9)\end{array}$ & $\begin{array}{c}\text { CPK } \\
(<60)\end{array}$ & $\begin{array}{c}\text { TBK } \\
(\mathrm{mmol} / \mathrm{l})\end{array}$ \\
\hline 1 & $1 \cdot 5$ & 40 & & & & \\
4 & $2 \cdot 0$ & 32 & 315 & 42 & 2261 & 1940 \\
6 & $2 \cdot 4$ & 30 & 146 & - & & \\
8 & $2 \cdot 8$ & 30 & - & 4 & 160 & \\
11 & $3 \cdot 4$ & 28 & 26 & - & 97 & 2231 \\
12 & $2 \cdot 8$ & 24 & - & 4 & - & 2255 \\
14 & $4 \cdot 2$ & 26 & 18 & - & 6 & \\
25 & & & & 6 & 6 & \\
\hline
\end{tabular}

Normal ranges are given in brackets, enzyme values in i.u./l. AST=aspartate transaminase; GOT=glutamic oxalo-acetic transaminase; $\mathrm{CPK}=$ creatine phosphokinase; $\mathrm{TBK}=$ total body potassium. 
Table 1, her TBK increased and the plasma potassium, and the muscle enzymes, subsequently returned to normal. Plasma aldosterone was measured 2 months later and was normal. The patient was advised to avoid liquorice in future.

\section{Discussion}

This patient who had been eating $500 \mathrm{~g}$ of liquorice per week for many years developed a myopathy and hypokalaemic alkalosis. The administration of a diuretic 2 weeks before admission might have been the aggravating factor in this patient; liquorice has been known to cause oedema (Revers, 1948). The hypokalaemia is thought to be due to the aldosteronelike action of its active principle - glycyrrhizinic acid (Card et al., 1953; Groen et al., 1951, 1952; Louis and Conn, 1956) - and this is known to be associated with muscle weakness, necrosis of muscle fibres and ECG changes (Cumming, 1977; Gross et al., 1966; Salassa et al. . 1962). The present patient showed severe muscle weakness, muscle necrosis (increased CPK, aldolase and AST) and oedema, but did not display any ECG changes. A $20 \%$ deficit in total body potassium in this patient was also shown. Although weakness due to chronic ingestion has been reported previously (Cumming, 1977; Gross et al., 1966; Salassa et al., 1962), there are no reports on total body potassium measurements in these patients. In spite of a $20 \%$ deficit of total body potassium, there were no ECG changes in this case. It is possible that skeletal muscle damage and cardiac changes due to hypokalaemia might have different mechanisms. It is also interesting to note that the patient's muscle power improved dramatically within $48 \mathrm{hr}$ of stopping liquorice, with only a small increase in plasma potassium $(0.5 \mathrm{mmol} / \mathrm{l})$ during that period. Thus, it appears that the severity of muscle weakness does not correlate with the degree of hypokalaemia. The object of this report is also to stress the potential hazard of chronic liquorice consumption, even as a sweet.

\section{Acknowledgments}

We thank Dr Robson Parsons for his advice and permission to study this patient. We also thank Professor D. B. Morgan and Dr L. Burkinshaw for their help.

\section{References}

Card, W.I., Mitchell, W., Strong, J.A., Taylor, N.R.W., TOMPSETT, S.L. \& WILSON, J.M.G. (1953) Effects of liquorice on salt and water metabolism. Lancet, i, 663.

ConN, J.W., Rovner, D.R. \& COHEN, E.L. (1968) Liquoriceinduced pseudoaldosteronism. Journal of the American Medical Association, 205, 492.

Cumming, A.M.M. (1977) Metabolic effects of liquorice. British Medical Journal, 1, 906.

Groen, J., Pelser, H., Willebrands, A.F. \& Kamminga, C.E. (1951) Extract of licorice for the treatment of Addison's disease. New England Journal of Medicine, 244, 471.

Groen, J., Pelser, H., Frenkel, M., Kamminga, C.E. \& WILLEBRANDS, A.F. (1952) Effect of glycyrrhizinic acid on the electrolyte metabolism in Addison's disease. Journal of Clinical Investigation, 31, 87.

Gross, E.G., Dexter, J. D. \& Roth, R.G. (1966) Hypokalemic myopathy with myoglobinuria associated with licorice ingestion. New England Journal of Medicine, 274, 602.

LouIs, L.H. \& ConN, J.W. (1956) Preparation of glycyrrhizinic acid, the electrolyte active principle of licorice: Its effects upon metabolism and upon pituitary-adrenal function in man. Journal of Laboratory and Clinical Medicine, 47, 20.

REVERS, F.E. (1948) Behandeling van uleus ventriculi in uleus duodeni met succus liquiritiae. Nederlands Tijdschrift voor Geneeskunde, 92, 2968.

Salassa, R.M., Mattox, V.R. \& Rosevear, J.W. (1962) Inhibition of the mineralocorticoid activity of licorice by spironolactone. Journal of Clinical Endocrinology and Metabolism, 22, 1156. 